\title{
In vitro Antioxidant, Cytotoxic and Membrane Stabilizing Activities of Bauhinia acuminata $\mathrm{L}$.
}

\author{
Mohammad Firoz Khan ${ }^{1}$, Rabeya Islam Shilpi ${ }^{1}$, Ridwan Bin Rashid ${ }^{2}$ and \\ Mohammad A. Rashid ${ }^{3}$ \\ ${ }^{1}$ Department of Pharmacy, State University of Bangladesh, Dhaka- 1205, Bangladesh \\ ${ }^{2}$ Department of Microbiology, University of Dhaka, Dhaka- 1000, Bangladesh \\ ${ }^{3}$ Department of Pharmaceutical Chemistry, University of Dhaka, Dhaka- 1000, Bangladesh
}

\begin{abstract}
The crude methanol extract of leaves of Bauhinia acuminata and its Kupchan fractions were screened for antioxidant, cytotoxic and membrane stabilizing activities. Among all partitionates the aqueous soluble fraction of B. acuminata demonstrated the highest antioxidant activity with $\mathrm{IC}_{50}$ value of $7.22 \pm 0.200 \mu \mathrm{g} / \mathrm{ml}$. Moreover, the carbon tetrachloride soluble fraction showed significant cytotoxic activity having $\mathrm{LC}_{50}$ value of $12.13 \pm 0.215$ $\mu \mathrm{g} / \mathrm{ml}$. On the other hand, in hypotonic solution- and heat- induced conditions, the crude methanol extract inhibited haemolysis of human erythrocyte by $63.94 \pm 0.14 \%$ and $51.95 \pm 0.20 \%$, respectively as compared to $81.97 \pm 0.77 \%$ and $42.11 \pm 0.39 \%$ demonstrated by the standard acetyl salicylic acid.
\end{abstract}

Key words: Bauhinia acuminata, antioxidant, cytotoxic and membrane stabilizing.

\section{Introduction}

Bauhinia acuminata L. (Common Name- Dwarf White Bauhinia, Family- Fabaceae) is a species of flowering shrub native to tropical southeastern Asia. The bark, flower and root of the B. acuminata are used for various skin diseases, worms, tumours and diabetes (Ayurvedic Medicinal Plants). The bark and leaves of $B$. acuminata is used to treat biliousness (Timothy, 1999), a remedy recommended by the Indian Vaiydas (Khare, 2007). In Malaysia and Indonesia the plant is used in the treatment of common cold and cough (Timothy, 1999). While in India the leaves and bark of this plant are used for treating asthma attack (Khare, 2007). Moreover, the leaf of B. acuminata is used to treat bladder stone, venereal diseases, leprosy, asthma and digestive diseases (FloraCafe). In contribution of our ongoing efforts to study medicinal plants of Bangladesh (Sikder et al., 2013, Chowdhury et al., 2013, Sharmin et al., 2013), the present study has been undertaken and we, herein, report the antioxidant, cytotoxic and membrane stabilizing properties of the leaf of B. acuminata for the first time.

\section{Materials and Methods}

Plant materials: The leaves of $B$. acuminata were collected from Khulna and a voucher specimen (DUSH10775) for this plant sample has been deposited in the Department of Botany, University of Dhaka for future reference.

Extraction and fractionation: The collected palnt parts were sun dried for several days and then oven dried for 24 hours at $40^{\circ} \mathrm{C}$ to facilitate grinding. The powdered whole plant (600 gm) of B. acuminata was extracted with about $1.5 \mathrm{~L}$ methanol for 7 days and then filtered through a cotton plug followed by Whatman filter paper number 1 . The extract was then concentrated by using a rotary evaporator at reduced temperature $\left(40-45^{\circ}\right.$ C) and pressure. The concetrated methanol extract (ME) was partitionated by the modified Kupchan method (Van Wagenen et al., 1993) and the resultant patitionates i.e., methanol extract (ME), pet ether (PE), carbon tetrachloride (CT), chloroform (CL) and aqueous (AQ) soluble materials were used for different biological screenings. 
Antioxidant activity: The free radical scavenging activity of the plant extracts on the stable radical 1,1diphenyl-2-picrylhydrazyl (DPPH) was estimated by the method of Brand -Williams (Wichi, 1988; Auddy et al., 2003). Then $\%$ inhibitions were plotted against respective concentrations used and from the graph $\mathrm{IC}_{50}$ was calculated by using tert- butyl-1-hydroxytoluene (BHT), a potential antioxidant as positive control.

Cytotoxic screening: This technique was applied for the determination of general toxic property of the plant extractives by using established protocol (Meyer et al., 1982; McLaughlin et al., 1998) against Artemia salina in a 1-day in vivo assay. Vincristine sulphate was used as positive control.

Membrane stabilizing activity: The membrane stabilizing activity of the extractives was assessed by evaluating their ability to inhibit hypotonic solution- and heat- induced haemolysis of human erythrocytes following the method developed by Omale et al. (2008).

Statistical Analysis: Three replicates of each sample were used for each assay to facilitate statistical analysis and the values are reported as mean $\pm \mathrm{SD}$.

\section{Result and Discussion}

The methanol extract of $B$. acuminata as well as different Kupchan partitionates derived from it were subjected to assay for total phenolic content, free radical scavenging activity, cytotoxic and membrane stabilizing activities. The total phenolic content in crude methanol extract and its pet ether, carbon tetrachloride, chloroform and aqueous soluble fractions were found to be $48.06 \pm 0.50, \quad 47.81 \pm 0.63, \quad 13.98 \pm 0.41, \quad 18.43 \pm 0.07$ and $18.55 \pm 0.10 \mathrm{mg} \mathrm{GAE} / \mathrm{gm}$ of sample, respectively (Table 1). The result indicated the presence of highest amount of phenolic compounds in the crude methanol extract and its pet ether soluble fraction.

Different partitionates of methanol extract of B. acuminata were also tested for free radical scavenging activity using DPPH. The $\mathrm{IC}_{50}$ values of the extractives were found in the range of $7.22 \pm 0.200 \mu \mathrm{g} / \mathrm{ml}$ to $79.93 \pm 0.412 \mu \mathrm{g} / \mathrm{ml}$. Among all the partitionates the aqueous soluble fraction and crude methanol extract showed highest $\left(\mathrm{IC}_{50}=\right.$ $7.22 \pm 0.200 \mu \mathrm{g} / \mathrm{ml}$ and $8.82 \pm 0.412 \mu \mathrm{g} / \mathrm{ml}$ ) free radical scavenging activity (Table 1).
Table 1. IC $_{50}$ values of standard and different partitionates of B. acuminata in DPPH assay.

\begin{tabular}{lc}
\hline Samples & $\mathrm{IC}_{50}(\mu \mathrm{g} / \mathrm{ml})$ \\
BHT & $21.20 \pm 0.520$ \\
AQ & $7.22 \pm 0.200$ \\
ME & $8.82 \pm 0.412$ \\
CL & $16.03 \pm 0.312$ \\
CT & $26.88 \pm 0.215$ \\
PE & $79.93 \pm 0.412$ \\
\hline
\end{tabular}

$\mathrm{BHT}=$ tert- butyl-1-hydroxytoluene, $\mathrm{AQ}=$ Aqueous soluble fraction, $\mathrm{ME}=$ Methanol extract, $\mathrm{CL}=$ Chloroform soluble fraction, $\mathrm{CT}=$ Carbon tetrachloride soluble fraction, $\mathrm{PE}=$ Pet ether soluble fraction.

In Brine shrimp lethality bioassay the median lethal concentration $\left(\mathrm{LC}_{50}\right)$ of the test samples after 24 hours was obtained by a plot of percentage of the shrimps killed against the logarithm of the sample concentration and the best-fit line was obtained from the graph by means of regression analysis. Among all the partitionates of crude methanol extract of $B$. acuminata, the carbon tetrachloride soluble fraction displayed highest lethality having $\mathrm{LC}_{50}$ value $12.13 \pm 0.215 \mu \mathrm{g} / \mathrm{ml}$.

Table 2. $\mathrm{LC}_{50}$ values of standard and different partitionates of $B$. acuminata in brine shrimp lethality bioassay.

\begin{tabular}{llll}
\hline $\begin{array}{l}\text { Test } \\
\text { samples }\end{array}$ & Regression line & $\mathrm{R}^{2}$ & $\mathrm{LC}_{50}(\mu \mathrm{g} / \mathrm{ml})$ \\
\hline $\mathrm{VS}$ & $\mathrm{y}=30.8 \mathrm{x}+60.64$ & 0.972 & $0.451 \pm 0.041$ \\
$\mathrm{PE}$ & $\mathrm{y}=47.71 \mathrm{x}-14.52$ & 0.866 & $22.51 \pm 0.122$ \\
$\mathrm{CT}$ & $\mathrm{y}=36.64 \mathrm{x}+10.29$ & 0.926 & $12.13 \pm 0.215$ \\
$\mathrm{CL}$ & $\mathrm{y}=34.62 \mathrm{x}-9.196$ & 0.911 & $51.27 \pm 0.145$ \\
ME & $\mathrm{y}=44.89 \mathrm{x}-17.00$ & 0.881 & $31.08 \pm 0.035$ \\
\hline
\end{tabular}

$\mathrm{VS}=$ Vincristine sulfate, $\mathrm{PE}=\mathrm{Pet}$ ether soluble fraction, $\mathrm{CT}=$ Carbon tetrachloride soluble fraction, $\mathrm{CL}=$ Chloroform soluble fraction, $\mathrm{ME}=$ Methanol extract.

At concentration of $1.0 \mathrm{mg} / \mathrm{ml}$, different partitionate fractions of $B$. acuminate protected the haemolysis of RBC induced by hypotonic solution and heat as compared to the standard acetyl salicylic acid. The crude methanol extract inhibited $63.94 \pm 0.14 \%$ and $51.95 \pm 0.20 \%$ of haemolysis of RBC induced by hypotonic solution and 
heat as compared to $81.97 \pm 0.77 \%$ and $42.11 \pm 0.39 \%$ by acetyl salicylic acid, respectively (Table 3).

Table 3. Percentage (\%) inhibition of heat and hypotonic solution induced haemolysis of erythrocyte membrane by standard and different partitionates of $B$. acuminate.

\begin{tabular}{lcc}
\hline \multirow{2}{*}{ Samples } & \multicolumn{2}{c}{ \% Inhibition of haemolysis } \\
\cline { 2 - 3 } & Heat induced & $\begin{array}{c}\text { Hypotonic solution } \\
\text { induced }\end{array}$ \\
\hline Hypotonic medium & - & - \\
CL & $31.20 \pm 0.03$ & $64.03 \pm 0.51$ \\
ME & $51.95 \pm 0.20$ & $63.94 \pm 0.14$ \\
CT & $84.35 \pm 0.15$ & $38.76 \pm 0.52$ \\
PE & $38.18 \pm 0.86$ & $29.34 \pm 1.01$ \\
ASA & $42.11 \pm 0.39$ & $81.97 \pm 0.77$ \\
\hline
\end{tabular}

$\mathrm{CL}=$ Chloroform soluble fraction, $\mathrm{ME}=$ Methanol extract, $\mathrm{CT}=$ Carbon tetrachloride soluble fraction, $\mathrm{PE}=\mathrm{Pet}$ ether soluble fraction, ASA= Acetyl salicylic acid

\section{Acknowledgement}

The authors wish to acknowledge the Phytochemical Research Laboratory of State University of Bangladesh for providing necessary facilities to carry out the work.

\section{References}

Auddy B., Ferreira F., Blasina L., Lafon F., Arredondo F., Dajas R. and Tripathi P.C. 2003. Screening of antioxidant activity of three Indian medicinal plants, traditionally used for the management of neurodegenerative diseases. $J$. Ethnopharmacol. 83, 131-138.
Ayurvedic Medicinal Plants: Bauhinia acuminata (http://www.toxicologycentre.com/English/plants/Botanical /vellamandram.html)

Chowdhury F., Pal S., Sharmin T., Rashid R.B., Sikder A., Kabir S., Rahman M. S. and Rashid M.A. 2013. Bioactivities of artocarpus chaplasha Roxb. and Bougainvillea spectabillis Willd. Bang. Pharm. J. 16, 63-68.

FloraCafe (http://floracafe.com/Search_PhotoDetails.aspx?Photo $=$ Top $\& I d=3065 \&$ show $=$ Medicinal)

McLaughlin J.L., Anderson J.E., Rogers and Lingling L. 1998. Drug Info. J. 32, 513-524.

Khare C.P. 2007 Indian Medicinal Plants: An Illustrated dictionary. Springer-Verlag Berlin, p. 85.

Meyer, B.N., Ferringni, N.R., Puam, J.E., Lacobsen, L.B., Nichols, D.E. 1982. Drug Info. J. 31, 516-554.

Omale, J. and Okafor, P.N. 2008. Comparative antioxidant capacity, membrane stabilization, polyphenol composition and cytotoxicity of the leaf and stem of Cissus multistriata. Afr. J. Biotechnol. 7, 3129-3133

Sharmin T., Islam F., Sikder A., Kabir S., Haque M.R. and Rashid M.A. 2013. Membrane stabilizing and Preliminary Hypoglycemic activities of picrasma javanica. 2013. Bang. Pharm. J. 16, 89-92.

Sikder M.A., Saha R., Rokibuzzaman M., Sharmin T., Rashid R.B., Uddin M.Z. and Rashid M.A. 2013. Preliminary biological investigations of Lophopeyalum fimbriatum and Calophyllum inophyllum. Bang. Pharm. J. 16(2), 205-209.

Timothy Johnson. 1999. CRC ethnobotany desk reference, CRC press LLC Boca Taton, p. 110.

Wichi, H.P. 1988. Enhanced tumor development by butylated hydroxylanisole (BHA) from the proseceretive of effects of forestomach and esophagealsqumous epithelium. Food Chem. Toxicol. 26, 717-723. 